This is an author produced version of a paper published in Desalination. This paper has been peer-reviewed and is proof-corrected, but does not include the journal pagination.

Citation for the published paper:

Dalahmeh, S. S., Assayed, M., Suleiman W. T. (2009) Themes of stakeholder participation in greywater management in rural communities in Jordan. Desalination.

Volume: 243 Number: 1-3, pp 159-169.

http://dx.doi.org/10.1016/j.desal.2008.04.022

Access to the published version may require journal subscription. Published with permission from: Elsevier

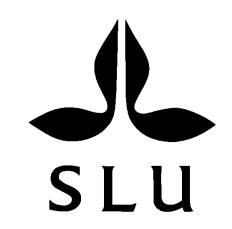

Epsilon Open Archive http://epsilon.slu.se 


\title{
Themes of Stakeholders Participation in Greywater Management in The Rural Communities in Jordan
}

Sahar S. Dalahmeh, Moayyed K. Al Sayyed, Wael T.Suleiman,

Environmental Research Center, Royal Scientific Society

P.O Box (1438) Al Jubaiha (11941) Jordan, Fax 96265340373

Email of Corresponding Author: sahar@rss.gov.jo; sahar_dalahmeh@yahoo.com

\begin{abstract}
This paper aims at documenting the experience of the Environmental Research Center at the Royal Scientific Society in stakeholder participation in greywater management (treatment and reuse) in the rural communities in the Northeastern Badia of Jordan. Stakeholders participated in the management process included local people, non governmental organization, community based organizations, governmental authorities, scientists and experts from universities and research institutions. Local stakeholders committee, NGOs, CBOs and local people have participated in capacity building programs, data collection, situation analysis, problems identification, selection of types and locations of treatment technologies and construction and operation of treatment units and reuse projects. Experts, scientists and governmental entities contributed to the development of a treatment technology selection matrix and identification the best technology that suits the study area. The study reveals that the incorporation of inputs from broad range of sectors and stakeholders during the project, insured cooperative management of the greywater resources, and enhanced project quality and ownership.
\end{abstract}

\section{KEY WORDS}

Integrated Management, Greywater, Stakeholders, Public Participation, Rural Communities, Badia, Steering Committee, Community Selection Criteria, Treatment Technology Selection Matrix.

\section{INTRODUCTION}

Jordan is one of the Middle East Arab countries, situated between $29^{\circ}$ and $33^{\circ} \mathrm{N}$ and $35^{\circ}$ and $39^{\circ} \mathrm{E}$; it has an area of $89300 \mathrm{~km}^{2}$. The total population of the country is about (5.18M capita), $72 \%$ of which is settled in the urban large cities in Jordan, whereas, $28 \%$ of which is settled in small scattered rural communities [1]. The Small communities are those communities with population size less than 5000 people [2].

The study area is the northeastern Badia of Jordan. Badia is a local term of the Jordanian dry lands where the local nomadic and non nomadic Bedouins used to live. The Northeastern Badia of Jordan extends to cover an area of about $(25,600) \mathrm{km}^{2}$. The population size of the northeastern Badia is about $(28,480)$ in 2003 living in (33) small communities. Towns and villages of the Badia sprawled horizontally and have low population density. [3]

The household sanitation facilities in Badia were built to satisfy households demand for privacy and convenience (outdoor toilets and indoor shower rooms). The cultural and religious traditions of Muslim communities of the Badia reveal water based sanitation which 
requires the use of water for ablution and washing after defecation.[4]

The current greywater use practices in the rural communities in Jordan are represented by the indigenous separation of greywater. Toilet wastewater is disposed to cesspools and greywater (which is wastewater effluent from the ablusion or handwashing basin, kitchen sink, shower room, bath tubs, and washing machine) is either used for irrigation or disposed directly to the environment without treatment [5].

The driving forces behind greywater separation are three fold: religious attitudes and beliefs, scale of economy, and water demand management [6]. According to the teachings of Islam, water becomes wastewater (unclean: mutanajjis) as a result of mixing with pollutants or because it is used by humans for personal cleanliness [7]. Based on these teachings, people are not tempted to discharge the ablution water and kitchen water to the same cesspool of the black wastewater. They believe that kitchen greywater contains some food remains (Allah gifts) and should not be mixed with mutanajjis unclean water from toilets [6].

The aim of this paper is to illustrate the process of stakeholder participation in greywater management in the badia of Jordan The work was carried out in a project entitled "integrated wastewater management policies and technologies in the marginal communities in Jordan". The objective of the project was to improve the quality of life and well-being for rural Jordanians, strategically support greywater reuse and improve the hygienic conditions.

\section{METHODOLOGY}

\subsection{Mobilization}

Site visits were organized to most of the communities in the project area. Formal and informal informative meetings were held with community leaders and representatives, municipality directors, managers of female and male schools, and representatives of Non-Governmental Organizations NGOs and Community-Based Organizations CBOs to introduce the project idea, objectives, methodology of work and role of the community in greywater management.

\subsection{Formation of Local Stakeholders Committee}

A Local Stakeholder committee LSC was formed by the community itself. The committee comprises of 15 persons ( 4 females and 11 males) from different communities in the project area. The LSC has been involved in different activities of the project. The researchers together with the LSC meet regularly to discuss various issues related to greywater treatment and reuse.

\subsection{Formation of Steering Committee from Governmental Authorities}

A steering committee of members from Ministry of Water and Irrigation, Ministry of Health, Ministry of Environment, Badia Research and Development Center, as well as representative from the LSC was formulated. The role of the committee was to discuss different aspects of greywater management in the rural communities, future governmental plans and strategies for the development of integrated management of the Badia resources. 


\subsection{Formation of Expert Committee}

An expert committee that consists of scientist and experts from Royal Scientific Society, University of Jordan, Jordan University of Science and Technology, National Center for Agricultural Research and Technology transfer, Ministry of Water and Irrigation and InterIslamic Network on Water Resources

Development and Management was formulated. The role of the committee was to establish a network for discussion, information exchange, assessment and evaluation of affordable and attractive greywater treatment options that suits the study area.

\subsection{Capacity Building of Local Stakeholders} Committee

A 4-days training course on Participatory Development Communication PDC and Participatory Rapid Appraisal PRA was organized by research team and delivered by CARE International in Jordan/CARE Australia and PLAN:NET/Canada. The training targeted the LSC members and implemented in one of the CBOs in the study area. The training focused on the concept of participation, participatory rapid appraisal tools and methodology that could be used to identify wastewater problems and solutions based on the community's perspectives and needs with emphasis on the more salient issues such as inhabitants perceptions on water scarcity, greywater reuse at the household level as an effective water demand management strategy, and on-site wastewater management practices.

Five field trips were organized for the LSC and other community representatives. The first visit was to the western part of the country, Deir
Alla, where a wastewater treatment and reuse project serves (13) communities with a total population of about (6000) inhabitants. The second trip was to the southern part of Jordan, Wadi Mousa, where a treatment and reuse project is in operation since 2001 serving three small communities. Two other field visits were organized to a university campus in the northern part of the country, and to a near-by treatment and reuse project serving three small communities and a refugee camp. The fifth field visit was organized towards small communities in the southern part of Jordan, Karak and Tafielah cities, where a greywater treatment and reuse project serves several communities in the area

Moreover, environmental awareness campaigns targeted the community leaders, religious leaders (Imam: leader of prayers), housewives, teachers, school students, public health specialists. The awareness campaigns took the shape of lectures, group discussions, workshops and best environmental drawing contest. The lectures and discussions focused on

- Role of local people specially women in managing greywater resources,

- Role of religious leaders in water conservation and reuse conditions in Islam.

- Role of teachers in disseminating the information about greywater management to their students who transfer their new knowledge to their families.

- Methods and practices that improve the quality of the greywater at source

- Usages of treated greywater and health impacts of the direct contact to the untreated greywater.

\subsection{Participation of LSC in Data Collection}


Utilizing information learned throughout the PRA training workshop, the researchers and LSC prepared a checklist to identify social, economical as well as environmental and technical issues related to the study based on community's perspectives and needs. The checklist (shown in Table.1) was used as a tool to guide the team in collecting data during field visits to the households.

$(8-15 \%)$ of the population was included in data collection. 5 Work teams each consisted of 3-5 members including at least one female. A total of (404) meetings were carried out during (13) days of field work in 33 communities.

\subsection{Participation of LSC in Identification of an Appropriate Community}

The community selection criteria was set by the research team and LSC to identify 1-2 communities within the project area as the research site where field-pilot experiments for greywater collection, treatment and reuse are to be conducted. The community selection criteria included the following items:

- Opportunity to improve current wastewater management practices.

- Social acceptance and favorability for reuse.

- Representation and potential for replication in terms of environmental conditions, lifestyles and building styles.

- Institutional support and the presence of NGOs and/or CBOs.

\subsection{Participation in Greywater Quality and} Quantity Assessment
Six households were selected in cooperation with the LSC for the purpose of assessing quality and quantity of greywater generated in the community. Greywater quantities in the households were measured by one community member on daily basis. Expert and steering committees have participated in assessing the quality of greywater generated in the study area based on the available wastewater guidelines and standard of reuse.

\subsection{Participation in Selection of the Appropriate Treatment System}

An expert group consisting of the research team, expert committee and steering committee as well as a representative of the LSC worked on developing greywater treatment selection matrix, based on certain criteria takes into consideration greywater quality and quantity, community requirements, and local regulations, operation and maintenance requirements and local social, economical and environmental conditions. Five treatment technologies were evaluated in the view of the criteria. The technologies are: septic tank, sand filter, constructed wetlands, sequential batch reactor and up flow anaerobic sludge blanket UASB.

\subsection{Participation Of Local People In Construction And Operation Of The Treatment Unit}

The local people represented by the household owners participated in constructing the treatment units in their area. Septic tank followed by intermittent sand filter was constructed in Abu Al Farth village and up flow anaerobic sludge blanket reactor was constructed near Zamlat al Ameer Ghazi village. The units were built by the hand of the 
local people and by construction materials, fittings and machineries that are available in the area. The treatment units were operated and sometimes maintained by the hands of households' owners.

Figure. 1 shows schematic diagram for the flow of information between the different stakeholders and established bodies in the project.

\section{RESULTS}

\subsection{Mobilization and Capacity Building Programs}

Informative meetings enhance: (1) Initiating dialogue over the greywater issues in the rural communities in the badia and build common understanding of the relevant issues and problems with these communities. (2) understanding of the objectives, activities and outcomes of the intergraded greywater management policies and technologies in the marginal communities in Jordan. (3) understanding of the role of local people in the management process of greywater resources in their areas, and the importance of the public participation to the successfulness of the project.

The local stakeholder committee viewed the opinions and interests of the local communities. It worked as a connecting body between the local people and the other stakeholders such as project team, governmental authorities and research institution.

Gender participation was addressed in LSC by involving women from the local people, NGOs and CBOs. One third (4 women) of the local stakeholder committee were women.

\subsection{Public Participation in Data Collection and Situation Analysis}

Participatory Rural Appraisal (PRA) tools and community participation methodologies enabled LSC and communities to identify greywater problems and solutions based on the community's perspectives and needs.

LSC found that project area suffers a water shortage problem. Domestic water is being supplied through the public network only 24 hours a week; inhabitants purchase water from the private sector (water tankers) particularly in summer period. People spend 5\% of their income for the water bill. Agricultural activities in the area are limited and are only possible through irrigation; wheat and barley are the main crops. The main obstacle facing agriculture in the area is water scarcity.

The community relies mainly on unlined cesspools as an on-site wastewater collection system. Cesspools are rarely emptied at some clusters, and are pumped-out on monthly basis at other clusters with an average entailed cost of (21 JD/each pump-out). The closest legal liquid waste dumping site is $(80 \mathrm{~km})$ away from the area; inhabitants believe that wastewater pumped out of cesspools is being illegally disposed of in near-by streams. About $62 \%$ of the public in the project area utilize pit latrines or ventilated improved pit latrines, $33 \%$ have traditional (no-flush) in-door toilet, while only $1 \%$ use flush toilet ( $89 \%$ on the national level). Only $40 \%$ of the community has showers and kitchen sinks.

As for greywater, two-third of the community indigenously separate greywater from blackwater, mainly for religious considerations. Greywater is being reused directly (without any treatment) for irrigating planted areas in the backyards in an 
uncontrolled manner, paying no attention to health aspects.

The majority of the rural communities of the Badia region ascertains the existence of greywater problems that affect both public health and environment. The major public health issues attributed to greywater that are those related to the presence of insects, rodents and offensive odors.

\subsection{Participation in Identifying the} Appropriate Community

A community screening matrix shown in Table 2 was developed by the research team in cooperation with the local stakeholders committee. Out of 33 communities in the study area, 7 communities were screened. Out of the seven communities Abu Al Farth village and village near Zamlat Al Amir Ghazi selected to implement the treatment units in their territories.

\subsection{Participation of Expert and Steering Committee}

As a result of the participation of the expert committee, steering committee and research team a treatment technology evaluation matrix for five treatment technologies was developed as shown in Table 3. Based on the matrix, up-flow anaerobic sludge blanket UASB and septic tank followed by intermittent sand filter are the best technologies that suit greywater quality and quantity, environmental conditions, social and economical conditions of the study area.

\subsection{Construction and Operation of Treatment} Units
Septic tank followed by intermittent sand filter was constructed in single household in $\mathrm{Abu} \mathrm{Al}$ Farth village. Up flow anaerobic sludge blanket unit was constructed near Zamlat $\mathrm{Al}$ Amir Ghazi village. Construction of treatment units was accomplished by the help of the house owners and by manpower available in the study area utilizing local materials.

\section{DISCUSSION}

Providing the public with effective means of participations and building trust with the communities by involving them in the planning process early on -collecting data, assessing needs, building capacity, selecting alternative sites and technologies and having an input in the management wheel is most important tool that ensured the cooperative management of the resources in the rural communities and enhanced project quality, ownership and sustainability [8], [9].

The major challenge in community involvement in the rural communities in Jordan was developing the community know how in greywater related issues. This challenge was dealt with by facilitating dialogue over the greywater management issues and providing the opportunity for the interaction of the communities with the existing greywater related issues in Jordan. The level of understanding and the community knowledge towards greywater management and reuse issues were increased through awareness campaigns, site visits, training courses and workshops, regular meetings and group discussions.

The most critical factor for the success of a development project is the degree of public participation in decision making by local 
'beneficiaries' [10]. The local beneficiaries' participation in greywater management in the rural communities in Badia of Jordan was greater in the short term situation analysis phase and in the long term implementation phase than in the design phase. This is due to the fact the local people do not have the engineering backgrounds that enable them to take part in the design procedures. Moreover, the number of the treatment units was limited and thus limiting the opportunity of practicing the design exercise of the treatment units by communities. Though, the local people through Local Stakeholders Committee (LSC) have participated in deciding what type of the treatment technology that best suits their social and economical conditions by including their requirements. Moreover, local people thoroughly participated in data collection and in need assessment during the initial phase of the project, they were the source of the information that supplements the scarce resources. Moreover, the local people were responsible for the implementation of the management plan of the greywater resources in their area, i.e., operation, maintenance and monitoring of the greywater treatment units that were constructed in their vicinities.

Women played a significant role in promoting their indigenous knowledge in greywater management (separation and reuse of greywater) within their neighborhood and villages and by at-source enhancement of greywater quality. However, the inclusion of women in decision-making structures, does not automatically ensure that women's interests are voiced, as there exists power relations between men and women that result in unequal gender voices. i.e., women actively practice greywater management in their homes, whereas, deciding having a treatment unit constructed in the home is the man's decision.
The project thoroughly promoted the role of (CBOs) and LSC in the management process of the greywater, and it highlighted the important role played by these parties disseminating information, acting as a voice for communities and promoting grassroots involvement of the public in reclaimed greywater management issues in the rural communities of Jordan

\section{CONCLUSION}

- The integrated management of the reclaimed greywater in the rural communities is a critical challenge in the Badia of Jordan where traditions and local values are predominated. Nonetheless, it is of special importance for improving the quality of life of these marginalized communities. It highly hinges on early involvement of the communities in selection, design, implementation, operation and maintenance of the treatment systems that suit the local environmental conditions and social-economical circumstances.

- Knowledge of local people should be recognized and participatory approaches need to be applied when investigating integrated water resources management programs for small communities.

However, intensive awareness campaigns need to be implemented. Field visits of local people to wastewater treatment and reuse projects is important to develop community-based know-how and to share knowledge and ideas.

- Joining forces of the different stakeholders (local communities, governmental organizations and experts) 
made up for scarce learning (knowledge), human and financial, resources that are needed for developing a greywater treatment technology of the Badia region.

- The introduction of the common understanding between the local communities and the various overriding governmental parties is considered an efficient tool to make people more responsible and provide them with the support and the knowledge required. This approach guarantees sustainability of the project.

\section{ACKNOWLEDGMENT}

The authors would like to express their gratitude for the International Development Research Center (IDRC)/ Canada for the financial support that was directed to the Environmental Research Center to implement a project entitled "Integrated Wastewater Management Policies and Technologies in the Marginal Communities in Jordan" under which the different themes of stakeholder participation were explored and studied. Special thanks go for steering committee, expert committee and LSC for their active participation in this research without which the current work would not be accomplished and published.

\section{REFERENCES}

[1] Department of Statistics, "Statistical Yearbook”, Jordan, 2001.

[2] World Health Organization, Eastern Mediterranean Regional Office, Regional Center for Environmental Health Activities, "Appropriate Technology for Water Supply and Sanitation in Rural and
Peri-Urban Areas in Some Countries of the Eastern Mediterranean Region", Jordan, 1995.

[3] World Health Organization, Eastern Mediterranean Regional Office, Regional Center for Environmental Health Activities, "Guidelines on Sanitation for Small Communities", Jordan, 1993.

[4] W. Roderic, J.I Dutton, and A. Battikhi, "Arid Land Resources and Their Management: Jordan's Desert Margin", Jordan, 1998.

[5] O.R. Al Jayyousi, "Greywater Reuse: towards sustainable water management". Desalination, 156(2003) 181-192.

[6] Royal Scientific Society, "Integrated Wastewater Management Policies and Technologies in the marginal communities of Jordan, Technical Report”. Jordan, 2003-2007.

[7] S. Farooq and Z.Ansari, "Wastewater reuse in Muslim countries: An Islamic perspective", Journal of Environmental Management, Volume 7, Number $2 /$ March, 1983, Pages119-123.

[8] J. Ockelford and B. Reed, "Participatory Planning for Integrated Rural Water Supply and Sanitation Programmes: Guidelines \& Manual”. Water Engineering and Development Center, Loughborough University, England, 2002.

[9] R.Chambers, " The Origin and Practice of Participatory Rural Appraisal”. World Development, 0305-750X(94)E0029-W. [10] E. Anton, D. Malzbender, "Stakeholder Participation In Transboundary Water Management - Selected Case Studies", African Centre for Water Research, South Africa (2006). 


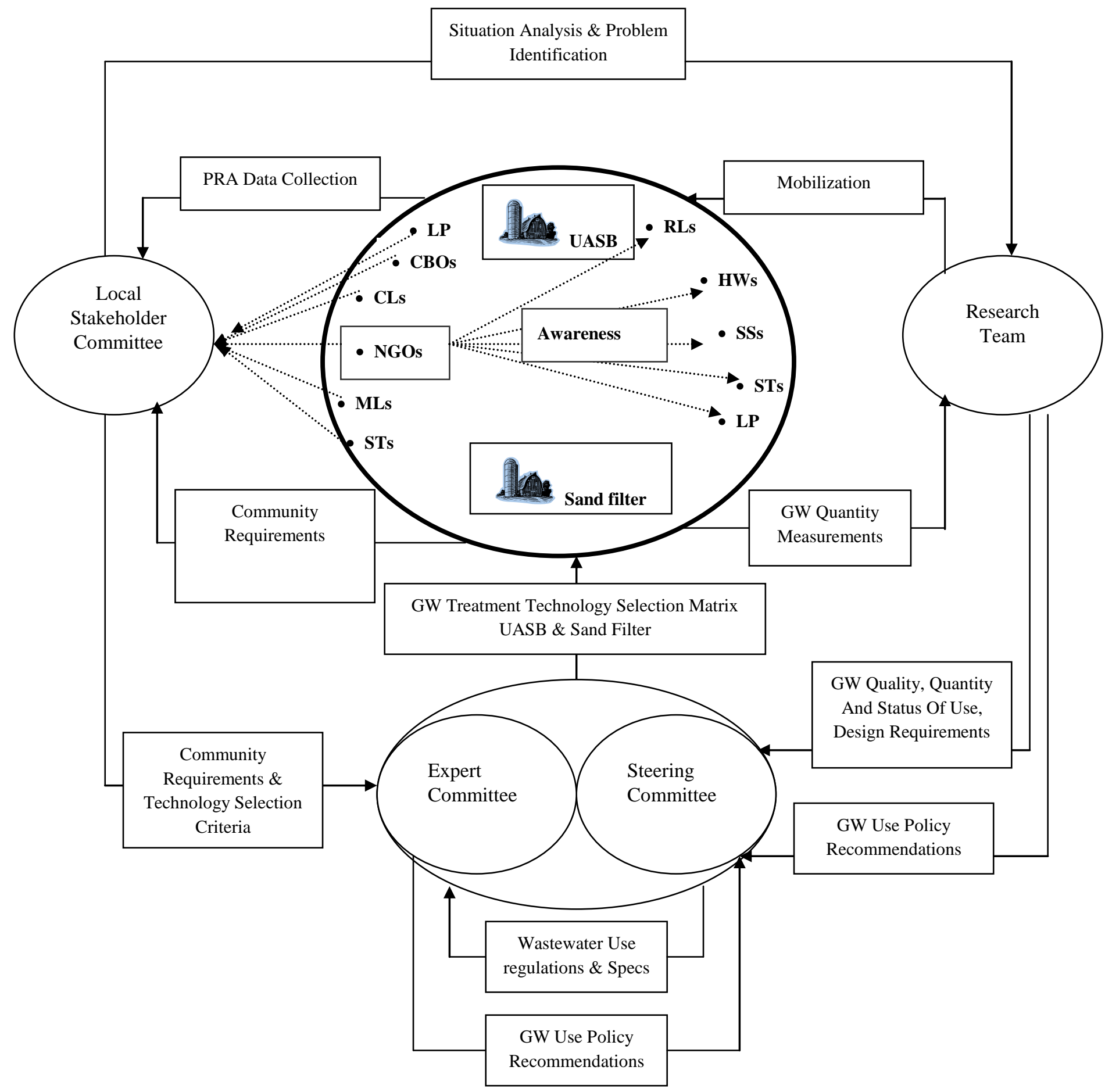

SSs: School students

RLs: Religious leaders

MLs: Municipality leaders

HWs: House wives

LP: Local People

GW: Greywater
STs: School teachers

CLs: Community leaders

UASB: Up flow anaerobic sludge blanket

NGOs: Non governmental organizations

CBOs: Community based organizations

PRA: Participatory rural appraisal

Location of treatment unit

Figure. 1: Information flow diagram between the different stakeholders in the project 
Table. 1 Data Collection Checklist prepared and used by the LSC.

\begin{tabular}{|c|c|c|c|}
\hline & Suggested Questions and Topics & Source of Data & PRA Tools to be used \\
\hline Social Issues & $\begin{array}{l}\text { - Number of family members and their educational levels. } \\
\text { - Number of wives. }\end{array}$ & $\begin{array}{l}\text { - Parents } \\
\text { - Family } \\
\text { members }\end{array}$ & $\begin{array}{l}\text { - Semi-structural } \\
\text { dialogue. } \\
\text { - } \quad \text { Direct observations. }\end{array}$ \\
\hline $\begin{array}{l}\text { Economical } \\
\text { Issues }\end{array}$ & $\begin{array}{l}\text { - Income sources and rates. } \\
\text { - Frequency and cost of cesspool pump-outs. } \\
\text { - Planted area around the residence and water sources for } \\
\text { irrigation. } \\
\text { - Number of owned livestock and drinking water sources. }\end{array}$ & - Parents & $\begin{array}{l}\text { - Semi-structural } \\
\text { dialogue. } \\
\text { - } \quad \text { Direct observations. }\end{array}$ \\
\hline $\begin{array}{l}\text { General } \\
\text { Available } \\
\text { Services }\end{array}$ & $\begin{array}{l}\text { Availability of different services (e.g. charity societies, } \\
\text { streets, schools, health-care centers, drinking water } \\
\text { networks, electricity, telephone networks, etc.). }\end{array}$ & $\begin{array}{l}\text { - Individuals } \\
\text { - Groups } \\
\text { - } \text { Municipality } \\
\text { - Charity } \\
\text { association }\end{array}$ & $\begin{array}{l}\text { - Semi-structural } \\
\text { dialogue. } \\
\text { - } \quad \text { Direct observations. }\end{array}$ \\
\hline Water Issues & 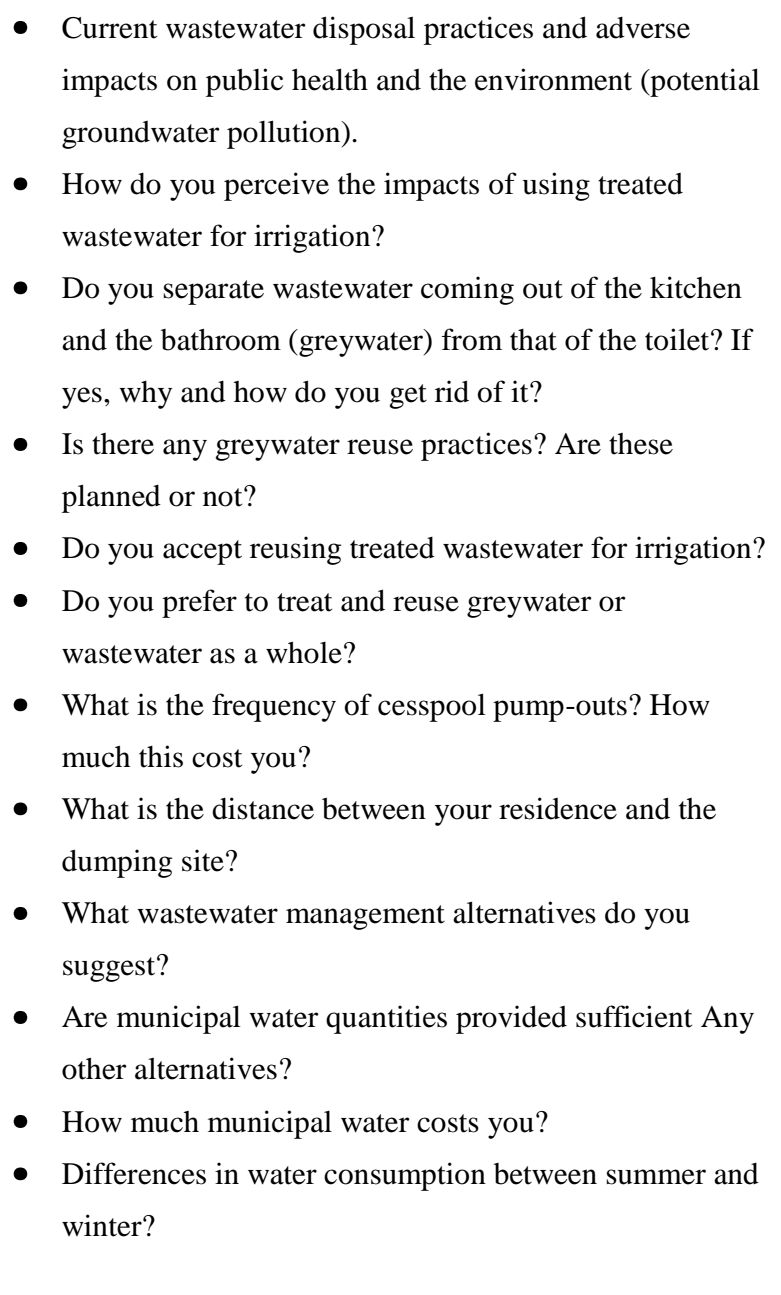 & $\begin{array}{l}\text { - } \text { Individuals } \\
\text { - } \text { Family } \\
\text { members } \\
\text { - } \text { Groups } \\
\text { - } \text { Municipality } \\
\text { - } \text { Charity } \\
\text { associations } \\
\\
\text { - } \text { Family } \\
\text { members } \\
\text { - } \text { Groups } \\
\text { - } \text { Municipality } \\
\text { Charity } \\
\text { associations }\end{array}$ & $\begin{array}{ll}\text { - } & \text { Semi-structural } \\
\text { - } & \text { dialogue. } \\
\text { - } & \text { Panking. } \\
\text { - } & \text { network. } \\
\text { - } & \text { Mapping. } \\
\text { - } & \text { Direct observations. } \\
\text { - } & \text { Seasonal calendar. } \\
\text { - } & \text { Historical background. } \\
\text { - } & \text { Daily routine. } \\
\end{array}$ \\
\hline
\end{tabular}


Table. 2 Community Screening Matrix.

\begin{tabular}{|c|c|c|c|c|c|c|c|}
\hline \multirow[b]{2}{*}{ Criteria } & \multicolumn{7}{|c|}{ Community / Score (out of 1.0) } \\
\hline & $\begin{array}{c}\text { Al } \\
\text { Ashrafiyya }\end{array}$ & Nayifa & $\begin{array}{l}\text { Rahbat } \\
\text { Racad }\end{array}$ & $\begin{array}{c}\text { Zumlet } \\
\text { Al-Ameer Ghazi }\end{array}$ & Qasim & $\begin{array}{l}\text { Abu-Al } \\
\text { Farth }\end{array}$ & $\begin{array}{c}\text { Khasha'a } \\
\text { Slaiteen }\end{array}$ \\
\hline $\begin{array}{l}\text { Opportunity to improve } \\
\text { current situation }\end{array}$ & 0.6 & 0.5 & 0.3 & 0.6 & 0.4 & 0.6 & 0.2 \\
\hline $\begin{array}{l}\text { Local acceptance and } \\
\text { favorability for reuse }\end{array}$ & 0.3 & 0.5 & 0.3 & 0.7 & 0.2 & 0.8 & 0.7 \\
\hline $\begin{array}{l}\text { Representativeness and } \\
\text { potential for replication }\end{array}$ & 0.6 & 0.7 & 0.8 & 0.8 & 0.8 & 0.9 & 0.5 \\
\hline $\begin{array}{l}\text { Institutional support (NGOs } \\
\text { and/ or CBOs) }\end{array}$ & 0.7 & 0.5 & 0.0 & 0.7 & 0.0 & 1.0 & 0.0 \\
\hline Total (out of 4) & 2.2 & 2.2 & 1.4 & 2.8 & 1.4 & 3.3 & 1.4 \\
\hline
\end{tabular}


Table. 3 Selection matrix of the greywater treatment systems.

\begin{tabular}{|c|c|c|c|c|c|c|}
\hline Criteria & Type of System & Septic Tank & $\begin{array}{l}\text { Intermittent } \\
\text { Sand Filter }\end{array}$ & Wetland & $\begin{array}{l}\text { Sequencing Batch } \\
\text { Reactor }\end{array}$ & $\begin{array}{c}\text { Up Flow } \\
\text { Anaerobic } \\
\text { Sludge Blanket }\end{array}$ \\
\hline \multirow{3}{*}{$\begin{array}{l}\text { Source } \\
\text { Characteristic }\end{array}$} & $\begin{array}{l}\text { Effective-ness in } \\
\text { Handling High } \\
\text { Organic Loads } \\
(\text { Yes/No) }\end{array}$ & Yes & No & No & Yes & Yes \\
\hline & $\begin{array}{c}\text { Removal } \\
\text { Effectiveness }\end{array}$ & $\begin{array}{c}\text { BOD: } 35 \% \text {, TSS: } \\
40 \%\end{array}$ & $\begin{array}{l}\text { BOD: } 90 \% \text {, } \\
\text { TSS: } 80 \%\end{array}$ & $\begin{array}{l}\text { BOD: } 40 \% \text {; } \\
\text { TSS: } 44 \% \text {, } \\
\text { N: } 33 \% \text {, } \\
\text { Pathogens: } \\
71 \% \\
\end{array}$ & $\begin{array}{l}\text { BOD: } 85 \% \text {, TSS: } \\
85 \% \text {, No Nitrogen } \\
\text { removal }\end{array}$ & COD: $75-90 \%$ \\
\hline & $\begin{array}{c}\text { Operate Under } \\
\text { Variable Flow } \\
\text { Patterns, Shock Loads } \\
\text { (Yes/No) }\end{array}$ & Yes & Yes & $\begin{array}{l}\text { Yes, need } \\
\text { stabilization } \\
\text { tank }\end{array}$ & $\begin{array}{c}\text { No, need } \\
\text { stabilization tank }\end{array}$ & Yes \\
\hline \multirow{6}{*}{$\begin{array}{l}\text { Community } \\
\text { Requirements }\end{array}$} & $\begin{array}{l}\text { Land Requirement } \\
\qquad\left(\mathrm{m}^{2}\right)\end{array}$ & $3 \mathrm{~m}^{3}$ & $10 \mathrm{~m}^{2}$ & $\begin{array}{c}25 \mathrm{~m}^{2} / 2 \mathrm{~m}^{3} \\
1-2 \mathrm{~m} 2 / 200 \mathrm{~L}\end{array}$ & $2 \mathrm{~m}^{2}$ & $\begin{array}{l}\text { Reactor of }(350 \\
\text { L capacity, } \\
\text { ith height of } \\
2 \mathrm{~m})\end{array}$ \\
\hline & $\begin{array}{c}\text { The Production of } \\
\text { Odors (yes/No) }\end{array}$ & $\begin{array}{l}\text { Yes, ventilation is } \\
\text { required }\end{array}$ & $\begin{array}{l}\text { Yes if open } \\
\text { filter }\end{array}$ & No & No & No \\
\hline & $\begin{array}{c}\text { Maintenance } \\
\text { Requirement (Daily, } \\
\text { Weekly, Monthly, } \\
\text { Yearly) }\end{array}$ & $\begin{array}{c}\text { Yearly } \\
\text { de-sludging }\end{array}$ & Monthly & $\begin{array}{l}\text { Monthly } \\
\text { Harvesting }\end{array}$ & Monthly & $\begin{array}{l}\text { De-sludging } \\
\text { every } 2 \text { years } \\
(100 \mathrm{~L} / \text { year })\end{array}$ \\
\hline & $\begin{array}{c}\text { Operation } \\
\text { Requirements, is it } \\
\text { User -Friendly } \\
\text { System? (Yes/No) }\end{array}$ & $\begin{array}{l}\text { No operation } \\
\text { requirements }\end{array}$ & $\begin{array}{l}\text { Yes ,mainte } \\
\text { nance of } \\
\text { laterals, } \\
\text { sprinklers, } \\
\text { backwashing } \\
\end{array}$ & $\begin{array}{l}\text { No operation } \\
\text { requirement; } \\
\text { but is still } \\
\text { not user } \\
\text { friendly } \\
\end{array}$ & $\begin{array}{l}\text { Yes, Power supply, } \\
\text { daily de-sludging }\end{array}$ & $\begin{array}{l}\text { No operation } \\
\text { requirement, } \\
\text { user friendly }\end{array}$ \\
\hline & $\begin{array}{c}\text { Approximate } \\
\text { Construction Costs } \\
\text { (JD) }\end{array}$ & $\begin{array}{l}400 \mathrm{JD} \text { (plastic } \\
\text { tank, fittings, } \\
\text { excavation) }\end{array}$ & $400 \mathrm{JD}$ & $120 \mathrm{JD} / \mathrm{m}^{2}$ & $\begin{array}{c}>1000 \mathrm{JD}, \text { (Air } \\
\text { Blowers, diffusers, } \\
\text { and Pneumatic } \\
\text { valves) }\end{array}$ & $300 \mathrm{JD}$ \\
\hline & $\begin{array}{c}\text { Approximate } \\
\text { Operation Costs (JD) }\end{array}$ & $\begin{array}{l}\text { 20JD/year (For } \\
\text { De-sludging) }\end{array}$ & -- & $\begin{array}{c}20 \mathrm{JD} / \\
\text { month } \\
\text { ( harvesting) } \\
+200 \mathrm{JD} \\
\text { Zeolite } \\
\text { replacement }\end{array}$ & $\begin{array}{l}\text { Power, sludge } \\
\text { disposal }\end{array}$ & Zero \\
\hline \multirow[t]{2}{*}{$\begin{array}{l}\text { Reuse } \\
\text { Opportunity } \\
\text { \& Local } \\
\text { Regulations }\end{array}$} & $\begin{array}{l}\text { The Effluent Quality } \\
\text { Meets the Jordanian } \\
\text { Specification } \\
\text { (893/2002) for } \\
\text { Restricted Irrigation } \\
\text { (Yes/No) }\end{array}$ & No & Yes & $\begin{array}{l}\text { Yes, but } \\
\text { depends on } \\
\text { surface area } \\
\text { of wetland }\end{array}$ & $\begin{array}{c}\text { Yes except for } \\
\text { Nitrogen and COD }\end{array}$ & Yes \\
\hline & $\begin{array}{c}\text { Losses, Evaporation, } \\
\text { High/Low) }\end{array}$ & Low & Moderate & High & Low & Low \\
\hline \multirow{2}{*}{$\begin{array}{l}\text { Receiving } \\
\text { Environment }\end{array}$} & $\begin{array}{c}\text { Need for Specific } \\
\text { Environmental } \\
\text { Conditions } \\
\text { (Temperature, } \\
\text { topography) (Yes/No) }\end{array}$ & Temp> $15 o C$ & No & No & $\begin{array}{l}\text { Topography: SBR } \\
\text { has to be mounted } \\
\text { above ground } \\
\text { surface to facilitate } \\
\text { de-sludging } \\
\end{array}$ & $\begin{array}{c}\text { Optimum } \\
\text { Temperature is } \\
35^{\circ} \mathrm{C} \text {. Isolation } \\
\text { is } \\
\text { recommended }\end{array}$ \\
\hline & $\begin{array}{c}\text { Availability of } \\
\text { Materials/ Media in } \\
\text { the Study Area } \\
\text { (Yes/No) }\end{array}$ & Yes & Yes & Yes & No & No \\
\hline
\end{tabular}


